\title{
ФОРМУВАННЯ МОВНОЇ КУЛЬТУРИ МАЙБУТНЬОГО ЛІКАРЯ ПРИ ВИВЧЕННІ МЕДИЧНОЇ ТЕРМІНОЛОГІЇ (ПРАКТИЧНІ МАТЕРІАЛИ)
}

Зевако В. І. Формування мовної культури майбутнього лікаря при вивченні медичної термінології (практичні матеріали).

У статті проаналізовані питання мовної культури у галузі медичної термінології, значення цього розділу для майбутніх фахівців та подано практичні матеріали, що використовується автором у викладанні курсу української мови (за професійним спрямуванням) при вивченні лексичних норм.

Ключові слова: культура мови, лексична норма, медична термінологія, практичне завдання.

Зевако В. И. Формирование речевой культуры будущого врача при изучении медицинской терминологии (практические материалы).

В статье проанализированы вопросы речевой культуры в области медицинской терминологии, значение этого раздела для будущих специалистов и поданы практические материалы, используемые автором в преподавании курса украинского языка (в профессиональном общении) при изучении лексических норм.

Ключевые слова: культура речи, лексическая норма, медицинская терминология, практическое задание.

Zevako V. I. The formation of future doctor's language culture when studying medical terminology (practical material)

The issues of language culture in the sphere of medical terminology are analyzed in the given article. There are presented the meaning of this section for future specialists and practical materials used by the author in teaching Ukrainian language course (for professional purposes) when studying lexical rules.

Key words: language culture, lexical norm, medical terminology, practical task.

«Пильно й ненастанно політь бур'ян...». Із цією мудрою порадоюнастановою Максим Рильський звертається до кожного з нас, і випливає вона $з$ глибокої синівської любові письменника до рідної мови, подиктована щирим прагненням позбутися мовних неоковирностей, що виникли як наслідок багатьох заборон уживати українську мову, утисків, чужинецької експансії, жаданням патріота бачити іiі «чистішою від сльози», зберегти ії красу і самобутність [1, с. 66].

Будучи засобом формування й формулювання думок, мова необхідна нам для розвитку розумових здібностей, здобуття й оволодіння різними видами знань. За допомогою мови людина реалізується як інтелектуальна, 
високоосвічена, духовна особистість. Найголовніше призначення мови комунікація. Спілкування, стосунки 3 іншими людьми $є$ життєвою потребою, а водночас і найбільшою розкішшю, яка дається людині.

Кожен, хто прагне досягти успіху, створити себе, неодмінно має оволодіти культурою мови, тобто навчитися дотримуватися усталених норм усної і писемної форм літературної мови, використовувати всі іiі виражальні засоби залежно від стилю, жанру, типу. Особливої актуальності це набуває для професійного мовлення, важливим i необхідним елементом якого $є$ термінологія.

Мета нашої роботи - представити й подекуди прокоментувати той практичний матеріал, що використовуємо в курсі української мови (за професійним спрямуванням) при вивченні медичної термінології.

Культура мови - мовознавча дисципліна, яка на основі даних лексики, фонетики, граматики, стилістики формує критерії усвідомленого ставлення до мови й оцінювання мовних одиниць і явищ, виробляє механізми нормування та кодифікації. Вона виконує регулювальну функцію, адже пропагує нормативність, забезпечує стабільність, рівновагу мови, хоч водночас живить ії й оновлює.

Питання мовної культури виступають об'єктом наукової уваги багатьох лінгвістів, зокрема Н. Бабич, В. Князєва, Л. Мацько, В. Мельничайка, І. Плотницької, П. Редіна, С. Шумовицької. Учені наголошують на необхідності визначення оптимальної мовленнєвої поведінки в певній ситуації, звертають увагу на важливість культури мовлення у професійно-кваліфікаційній характеристиці фахівців будьякого профілю.

Центральним поняттям культури мови є мовна норма. Норма властива кожній національній літературній мові як необхідна умова іiі існування. Мовною нормою виступає будь-яке лінгвальне явище звук, сполучення звуків, морфема, значення слова чи фразеологізму, форма слова, словосполучення і речення, що сприймається як зразок. Мовні норми обов'язкові в усному і писемному спілкуванні для всіх носіїв. Опанування літературних норм сприяє підвищенню культури мови, а висока мовна культура є свідченням культури думки.

Проблема мовної норми висвітлена у працях українських учених М. Пилинського, А. Коваль, І. Герман, С. Срмоленко К. Серажим, М. Кочергана.

Мовна культура є важливим складником особистості медичного працівника. Від мистецтва мовного спілкування суттєво залежать 
результати лікування. Медична практика доводить, що слово і ранить, і лікує; словом можна вбити, словом можна врятувати. Не випадково 3 давніх-давен за допомогою слова лікували. Слово лікаря є свідченням його милосердя, чуйності, загальної культури й освіченості $[4$, с. 179].

Тому лікар має вміти добирати мовностилістичні засоби і прийоми відповідно до умов і мети спілкування, передаючи певний психокультурний контекст. Саме це є стрижнем, на який нанизується професійні знання та вміння спеціаліста [5, с. 3].

Медицина є невід'ємною частиною національної культури, яка передбачає мову, традиції, історію. За родом своєї діяльності лікарю доводиться не тільки оперувати скальпелем, але й роз'яснювати, доводити, переконувати. Тому він повинен бути професійним комунікантом, уміти активно використовувати потенціал фахового мовлення, важливою складовою якого є термінологія.

Термінологічна лексика - один із найважливіших компонентів у процесі вивчення мови й опанування майбутнього фаху. Для формування мовної культури в царині терміновживання під час вивчення української мови (за професійним спрямуванням) використовуємо різноманітні завдання.

1. До поданих термінів доберіть потрібні визначення. Для виконання вправи не пропонуємо використовувати термінологічний словник, оскільки більшість термінів студенти-першокурсники вже знають; невідомі слова вони характеризують самостійно, при необхідності виправляють у процесі перевірки. Зазвичай при виконанні вправи групу ділимо на 2 підгрупи для змагальності. Наприклад: аграфія - нарив, гнояк; агресія - відтинання шматочка ураженої тканини для мікроскопічного дослідження; амімія - організми, які живуть на тілі або в тілі інших організмів та живляться за їхній рахунок; амнезія ампутація; алексія - безсилий, кволий, млявий; автоклав - запалення грудної залози; абсиес - історія розвитку хвороби; авітаміноз лікувальні заходи, спрямовані на оживлення організму під час клінічної смерті, відновлення його функцій; алергія - запалення мозкових оболонок; анамнез - втрата здатності писати; анестезія - препарат, що вводиться в організм для попередження хвороб; апатія - схильність до нападу; апендицит - втрата пам'яті, забуття; астенічний - відсутність міміки; біопсія - знеболювання; вакцина - байдужість, кволість, бездіяльність; гематоскопія - апарат для стерилізації; гіпоксія похмурий, пригнічений настрій; крепітащія - недостатність або

(ㄱ В. І. Зевако, 2014. 
відсутність того чи іншого вітаміну в харчах; ларингіт - втрата здатності читати; мастит - синюшність; меланхолія - кисневе голодування; менінгіт - симптом захворювання, який проявляється як відчуття хрускоту; паразити - аналіз крові; реанімація - чутливість організму до чужорідних речовин, що вводяться повторно; утин - утворення жирових відкладень у підшкірній клітковині; ціаноз - запалення апендикса; целюліт - запалення слизової оболонки гортані.

Наводимо відповідники поданих термінів: аграфія - втрата здатності писати; агресія - схильність до нападу; амімія - відсутність міміки; амнезія - втрата пам'яті, забуття; алексія - втрата здатності читати; автоклав - апарат для стерилізації; абсцес - нарив, гнояк; авітаміноз - недостатність або відсутність того чи того вітаміну в харчах; алергія - чутливість організму до чужорідних речовин, що вводяться повторно; анамнез - історія розвитку хвороби; анестезія знеболювання; апатія - байдужість, кволість, бездіяльність; апендицит - запалення апендикса; асептики - запобігають зараженню рани шляхом стерилізації; астенічний - безсилий, кволий, млявий; біопсія відтинання шматочка ураженої тканини для мікроскопічного дослідження; вакцина - препарат, що вводиться в організм для попередження хвороб; гематоскопія - аналіз крові; гіпоксія - кисневе голодування; крепітація - симптом захворювання, який проявляється як відчуття хрускоту; ларингіт - запалення слизової оболонки гортані; мастит - запалення грудної залози; меланхолія - похмурий, пригнічений настрій; менінгіт - запалення мозкових оболонок; паразити - організми, які живуть на тілі або в тілі інших організмів та живляться за їхній рахунок; реанімаџія - лікувальні заходи, спрямовані на оживлення організму під час клінічної смерті, відновлення його функцій; утин - ампутація; ціаноз - синюшність; целюліт - утворення жирових відкладень у підшкірній клітковині.

\section{2. Розмежуйте значення паронімів, які мають широке} застосування в медичній галузі (у дужках наводимо значення слів). Цю вправу можна виконувати усно (характеризувати значення паронімів) або письмово (утворюючи словосполучення чи речення).

Кровний (рідний за кров'ю) - кров'яний (прикметник до кров) кривавий (з якого тече, виступає кров; колір; залитий кров'ю; жорстокий); шкірний (прикметник до шкіра) - шкіряний (зроблений зі шкіри); пітний (укритий потом) - потовий (який виділяє піт); психіатричний (стосується психіатріі) - психологічний (стосується

С В. І. Зевако, 2014. 
психології) - психічний (стосується психіки); афект (стан збудження) ефект (результат, дія); їа (дія за значенням їсти) - їжа (харчі); стрес (нервове напруження, переживання) - струс (різкий поштовх); гамувати (стримувати, заспокоювати) - тамувати (зупиняти); лікувати (дієслово до лікування) - лічити (дієслово до лічба); ліккарський (прикметник до лікар) - лікарський (прикметник до ліки) - лікарняний (прикметник до лікарня); хворовитий (схильний до захворювань) - хворобливий (викликаний хворобою; неприродний); криза (різка зміна речей; злам; загострення становища) - криз (раптове погіршення стану хворого); відносини (взаємини), відношення (причетність, зв'язки).

3. 3'ясуйте походження та значення слів, використовуйте термінологічні словники (у дужках наводимо потрібну інформацію).

Особливе місце при цьому займає робота 3 новітньою медичною термінологією, яка поповнює термінологічий склад української літературної мови. Для роботи рекомендуємо «Словник клінічних термінів російською, латинською та українською мовами» Н. Литвиненко та Н. Мисник [6].

Bазографія (лат. vas - судина, grapho - пишу) - рентгенологічне дослідження артерій і вен після введення у них контрастної речовини; ангіографія (грец. angeion - судина, grapho - пишу) - те саме, що вазографія; акомодація (лат. accomodatio - пристосування) - процес пристосування збудливої тканини; алерген (лат. allergenum чужорідний) - речовина, здатна спричинити алергію; нанізм (грец. nanos - гном, карлик) - карликовість, низькорослість; нанотехнології (нано префікс у системі одиниць СI, що означає множник $10^{-9}$ ), технологія (грец. technolohia - майстерність) - наука, яка вивчає закономірності фізичних і хімічних систем протяжністю близько кількох нанометрів або часток нанометра (нанометр - одна мільярдна частка метра або, що те ж саме, одна мільйонна частка міліметра; при цьому діаметр людської волосини становить близько 80 тис. нанометрів); наномедищина (див. нано, лат. medicina - мистецтво лікування, що від medicus - лікарський, лікувальний, medeor - лікую, зцілюю) - наука, яка застосовує результати нанотехнологій (пристрої, препарати, діагностикуми, біосенсори) у практичній діяльності; діагноз (грец. diagnosis - розпізнавання, визначення) - короткий лікарський висновок про характер i суть захворювання; токсикодермія (грец. toxicon - отрута, грец. derma, родовий відмінок від dermatos - шкіра) - різні види ураження шкіри, які виникають внаслідок реакції на контакт 3 будь-яким алергеном; 
остеосинтез (грец. osteon - кістка, synthesis - поєднання) - хірургічне з'єднання відламків кісток у правильному положенні з метою стабільної фіксації до повного кісткового зрощення і досягнення відновлення цілості й функції кістки; ращіон (лат. ratio - рахунок, міра) - склад i норма їжі, харчовий пайок для людини на певний проміжок часу; реабілітація (лат. re - знову, habilis - зручний, пристосований) комплекс заходів, спрямованих на відновлення порушених функцій організму, панацея (грец. Panakeia - всезцілителька) - богиня, дочка Асклепія, зцілителька людей. Цим ім'ям пізніше почали називати ліки, які нібито зцілюють від усіх хвороб) - лікарський засіб від усіх хвороб.

4. Доберіть синоніми або синонімічні словосполучення до поданих слів, охарактеризуйте їхні стилістичні та семантичні відтінки, визначте сферу вживання цих слів (у дужках наводимо синонімічні слова або словосполучення).

Білокрів'я (лейкемія, лейкоз); синюшність (синява, синюха, ціаноз); черевна порожнина (порожнина живота); ангіографія (вазографія); епідемічний паротит (свинка); хвороба Боткіна (гепатит А - вірусний гепатит); гематоскопія (аналіз крові); гіпоксія (кисневе голодування), іміас (невралгія сідничного нерва), круn (гостре запалення гортані й трахеї); пошесть (епідемія); хвороба (недуга, захворювання, хворість); пропасниця (малярія).

5. Доберіть українські відповідники до іншомовних термінів. Використовуйте словники медичних термінів та іншомовних слів (у дужках наводимо українські синоніми).

Анемія (недокрів’я); брадіакузія (туговухість, приглухуватість); вакцинація (щеплення); адаптація (пристосування); симптом (ознака); інсуфлячія (вдування); гемопоез (кровотворення); неоплазма (новоутворення); геморагія (крововилив); атрихоз (полисіння); лейкома (більмо); торакальний (грудний); иеребральний (мозковий); антитоксин (протиотрута); тонус (напруження); апатія (байдужість); вібрація (коливання); дезінфекція (знезараження); інвазія (зараження паразитами); респіраторний (дихальний); інспірачія (вдих); екстрений (невідкладний); маніпулящія (дія); тонізувати (поліпшувати); інтелект (розум); ефективний (дієвий); локальний (місцевий); латентний (прихований); гіпоксія (кисневе голодування); ціаноз (синюшність); мануальний (ручний); рефлексія (самоаналіз); резекція (видалення, відтинання, відрізання) сугестія (навіювання); аліментарний (харчовий); папула (пухир).

(ㄷ В. І. Зевако, 2014. 
В усному i писемному спілкуванні медичних працівників часто спостерігаємо надмірне вживання іншомовної термінології, яке загалом не порушує лексичної норми, але подекуди не відповідає таким ознакам культури мови, як доречність або ясність. Критерієм відбору для вживання слів іншомовного походження має бути семантична i стилістична необхідність їх застосування. П. Селігей переконує, що українська термінологія, зокрема і медична, в добу глобалізації повинна збагачуватися насамперед із першоджерел, варто переймати не англіцизми, а досвід англійської та інших мов творити і закріплювати в ужитку власні слова. Перенасичення запозиченнями у термінології зовсім не сприяє іiі розвитку. «Самоусунувшись від власного термінотворення й ставши покірним споживачем чужих слів, ми, по суті, ставимо хрест на тих скарбах, які наша мова нагромаджувала століттями» [3, с. 36].

6. До наведених словосполучень із довідки доберіть іншомовні відповідники (у дужках наводимо слова-синоніми).

Довідка. Анорексія, резистентність, кома, інволюція, коки, птоз, шпиталь, гіперстезія, атаксія, інтоксикація, тремор, генетика, ейфорія, домінанта, офтальмолог, синдром, латентний, параліч, анестезія, отит, неврит, енурез, ступор, депресія, поліневрит, нефрит, фобія.

Лікарня для військових (шпиталь); очний лікар (офтальмолог); відсутність чутливості (анестезія); відмова від їжі, втрати апетиту (анорексія); множинне запалення нервів (поліневрит); розлад координації (атаксія); наука про спадковість (генетика); втрата рухів (параліч); бактерї кулястої форми (коки); запалення вуха (отит); підвищена чутливість (гіперстезія); пригнічений стан (депресія); пануюча ознака (домінанта); запалення нирок (нефрит); опірність (резистентність); піднесений настрій (ейфорія); глибоке знепритомнення (кома); мимовільне сечовиділення (енурез); зворотний розвиток (інволюція); сукупність симптомів (синдром); опущення верхньої повіки (птоз); остовпіння, загальмованість (ступор); отруєння організму (інтоксикація); прихований (латентний); нав'язливий страх (фобія); тремтіння (тремор); запалення нерва (неврит).

У статті ми поділилися власними напрацюваннями в царині засвоєння медичних термінів, сподіваючись на те, що матеріали стануть у нагоді викладачам і студентам. Використання різних вправ і завдань, які відображають суть професійної діяльності, дає змогу стимулювати комунікативну активність майбутніх медичних працівників у навчальному процесі, відпрацьовувати професійно- 
мовленнєві навички в умовах, наближених до реальних.

Дотримання норм сучасної літературної мови $\epsilon$ обов'язковою умовою повноцінної, якісної діяльності фахівця-медика; їхнє порушення відображає низький рівень мовної компетенції. Тому, як зазначає М. Лісовий, «професійне мовлення <..> медичних працівників - це володіння нормами літературної мови, фаховою термінологією i стандартизованими мовленнєвими конструкціями медичної галузі, здатність використовувати мовні засоби відповідно до мети й ситуації спілкування» [2, с. 5].

\section{Література}

1. Антисуржик : Вчимося ввічливо поводитися і правильно говорити : [посібник] / [За заг. ред. О. Сербенської]. - Львів : Світ, 1994. - 152 с.

2. Лісовий М. I. Формування професійного мовлення майбутніх медичних працівників у вищих медичних навчальних закладах : автореф. дис. ... канд. пед. наук / М. І. Лісовий. - Вінниця, 2006. -20 с.

3. Селігей П. Чужого навчаємося, а свого цураємося... / П. Селігей // Дивослово. 2008. - № 7. - C. 36-40.

4. Цісар Т. І. Культура мовлення медика / Т. І. Цісар. - Кам'янець-Подільський, 2003. $-296 \mathrm{c}$.

5. Юкало В. Я. Культура мови : [навчальний посібник] / В. Я. Юкало. - Тернопіль : Укрмедкнига, 1999. - $77 \mathrm{c.}$

6. Литвиненко Н. П. Словник клінічних термінів : російською, латинською та українською мовами / Н. П. Литвиненко, Н. В. Мисник. - К. : Книга-плюс, 2014. -848 с.

Стаття надійшла до редакиії 17.09.2014 p. 